\title{
Economic Cycle, Uncertainty of Economic Policy and Cash Holding of Listed Companies
}

\author{
Qianqian Wang \\ Jinan University, Guangzhou, China \\ Email: mixcolor@foxmail.com
}

How to cite this paper: Wang, Q.Q. (2019) Economic Cycle, Uncertainty of Economic Policy and Cash Holding of Listed Companies. Modern Economy, 10, 281-297. https://doi.org/10.4236/me.2019.101019

Received: December 26, 2018

Accepted: January 19, 2019

Published: January 22, 2019

Copyright $\odot 2019$ by author(s) and Scientific Research Publishing Inc. This work is licensed under the Creative Commons Attribution International License (CC BY 4.0).

http://creativecommons.org/licenses/by/4.0/

\begin{abstract}
Based on the systematic review and economic analysis of the theoretical literature, we consider not only the impact of the economic cycle or the economic policy uncertainty (EPU) on the cash holding ratio, but also the comprehensive impact of the two on the cash holding rate. We raise the research hypothesis by using the data from 2004-2015 in the A-share listed companies which are listed in Shanghai and Shenzhen securities exchange as research samples. The empirical results show that: 1) There are respectively negative correlation between the economic cycle and the cash holding of listed companies, and positive correlation between the EPU and the cash holding. 2) During the boom, the cash holdings are significantly positive with the current EPU and the last stage; during the recession, the cash holdings of listed companies is significantly negatively correlated with the current EPU, while positive with the last stage. 3 ) We further examine the role of the economic cycle and the EPU on the cash holding value, and find that EPU will reduce the cash holding value. 4) When the economy is booming, the increase in EPU will reduce the market value of corporate cash holdings, but it is not significant. During recession, the increase in EPU will increase the market value of cash holdings.
\end{abstract}

\section{Keywords}

Economic Cycle, Economic Policy Uncertainty, Cash Holding, Cash Holding Value

\section{Introduction}

Cash is equivalent to the company's "blood", and holding liquid assets such as cash help companies to obtain valuable investment opportunities in the future [1]. In the theoretical range, scholars' research on corporate cash holdings has been enduring. As early as 1936, Keynes [1] proposed that the liquidity of cor- 
porate assets is restricted by external capital markets, and that the motives for holding cash are nothing more than trading and prevention.

After the outbreak of the financial crisis, the world economies have entered a period of recession. A large number of companies have been in financial crisis due to the impact of the macroeconomic environment, even bankrupt for the collapse of the capital chain. Many scholars have begun to pay attention to the macroeconomic environment for the company's liquidity management, especially the impact on the company's cash holding decisions. According to a study by Vinod [2], companies can respond to changes in the macroeconomic environment and quickly adjust the company's cash holdings to the optimal level recognized by management. In March 2009, the American Product and Quality Center (APQC) conducted a survey on corporate liquidity management. The results showed that increasing cash holdings and strengthening liquidity management have become the main positive responses to the financial crisis.

The economic cycle is an important variable in the macroeconomic environment and can affect the company's cash holding level by affecting external financing constraints. During recession, the company's operating income will be greatly reduced due to the shrinking market demand, affecting the company's cash flow, resulting in tight capital turnover. Meanwhile the company's external financing constraints are strengthened, financing capacity is reduced, and speculative motives are suppressed. In addition to the cash required to protect daily trading motives, the company will consider more of the uncertainty of the economic environment and increase cash holdings for preventive motives. Combined with the theory of financing constraints, Zhang Wenjun [3] defines this process as the transmission mechanism of "economic cycle fluctuations-financing constraints-liquidity management”. Considering that China's capital market is still immature, the external financing constraints faced by the company are widespread and strong. Therefore, the cash holding level of Chinese listed companies is higher than that of other countries such as the United States, Britain, Japan, Korea, India, Singapore [4], we can think that when economic cycle is in tight, the company's cash holdings will increase as the company's external financing constraints increase [5].

In addition to the high holding ratio, Chinese listed companies have the characteristics of large adjustment. The cash holding ratio of listed companies in China from the first quarter of 2004 to the fourth quarter of 2015 was within the range of $11.43 \%$ and $25.87 \%$, with the largest change of $5.5 \%$. (The data forming the above statistical results are from Csmar database.) Considering that the duration of the economic cycle does not explain this change well, and factors such as financial status, corporate governance, and industry competition are relatively stable for a certain period of time, and cannot explain it. Therefore, this paper also considers economic policy. The impact of uncertainty on a company's decision-making.

In addition to the economic cycle, economic policy uncertainty (EPU), as another variable in the macroeconomic environment, has a significant impact on 
the cash holdings of listed companies. EPU mainly affects the company's cash holding decisions in two ways: on the first hand the higher EPU, the more careful management will make investment decisions, and the total amount of corporate investment will fall [6], which will raise the level of corporate cash holdings from the outflow perspective; On the other hand, the increase in EPU will enable financial institutions to treat corporate financing needs more rigorously, increase corporate financing constraints, and enable companies to increase cash holdings for preventive motives.

There is a lot of debate about the relationship between economic cycles and EPU. Most scholars have found that EPU is countercyclical. Johannsen [7] found that fiscal policy uncertainty will lead to a sharp decline in consumption, investment and output, and the economic cycle will decline. Mumtaz et al. [8] determined that the time-varying monetary policy uncertainty was determined by stochastic volatility, and found that when the uncertainty increases, the nominal interest rate, output growth, and inflation fall. But Lee [9] found that as long as the market guarantees that productive companies can survive, EPU will promote exploratory research and innovation, and contribute to overall economic growth. When the macroeconomic environment changes, the government will carry out macroeconomic regulation and control in order to maintain market stability and achieve governance goals. For example, during recession, stable economic policies can reduce the impact of economic environment on the financing for enterprises, and weakening the impact of the economic cycle on the corporate cash holdings, and vice versa.

The purpose of this paper is to study the impact of macroeconomic cycle and EPU on the cash holding level of listed companies. Compared with other existing literatures, the innovation of this paper lies in the research on the combined impact of the macroeconomic cycle and EPU on the company's cash ratio. This paper theoretically enriches the mechanism and the economic consequences of the interaction of macroeconomic factors affecting business decision-making. The significance of this paper is to remind policy makers to distinguish the economic cycle from the stage of economic cycle when introducing policies. When the economy is booming, it should play more roles in the market and reduce the intervention in the market. In the recession period, appropriate policy intervention is beneficial to the whole market.

The rest of the paper is structured as follows: the second part is literature review and hypothesis development, the third part is research design, the fourth part is empirical analysis, and finally the conclusion and limitation.

\section{Literature Review and Hypothesis Development}

\subsection{Economic Cycle and Cash Holding}

Cash holding decisions are an important part of a company's business decisions. The company's cash holding behavior directly affects daily operations, financial conditions and investment decisions. In addition to the monetary funds in the 
financial statements, the cash in the cash holding level of this paper also includes short-term investments (pre-2006) and trading financial assets (post-2006), because of the characteristics of cash assets, easy trading, and short maturity,.

The existing literature on cash holding decision-making focuses on the impact of the company's financial status [10], governance structure [11] and industry competition [12] on the micro range. Most of the research on the impact of the macro environment on corporate cash holding decisions is related to financing constraints. Fazzari [13] and others used various investment models to test that the investment of companies with large financing constraints is more sensitive to cash flow. The study by Opler et al. [14] also proves financial constraints and the relevance of the decision of corporate cash holdings.

Bernanke and Gertler [15] found that the external financing ability of enterprises is largely plagued by economic cycle fluctuations. Since capital markets often have a series of barriers that are considered uncontrollable. External financing costs are common in terms of financing costs, and higher than internal financing costs, resulting in financing constraints. Baum et al. [16] found that when macroeconomic uncertainty is high, companies will increase their cash holdings and improve their ability to cope with future risks and investments for preventive motives. Generally speaking, during the economic boom period, external financing is more harmonious, and the company will reduce the company's cash holdings and increase the scale of transactions. However, when the economic cycle enters a tightening period, the company's financing capacity declines, and the company's management team will increase the company's cash holdings, actively respond to possible financial distress, or ensure the steady growth of the company's investment level. Therefore, compared with the period of economic expansion, the company's cash holdings during the economic contraction period show that enterprises have higher cash holding levels, and Jiang Long and Liu Xiaosong [17], Ni Huiping and Zhao Shan [18] also support the opinion. Based on the above analysis, we propose the following hypothesis:

H1: Economic cycle is negatively correlated with the cash holding level of listed companies.

\subsection{EPU and Cash Holding}

EPU will increase the uncertainty of the environment in which the company is located, and increase the systemic risks faced by enterprises [19], which will affect the company's cash holdings in two ways: cash inflows and cash outflows. Bai et al. [20] explored the global financial crisis and found that the uncertainty of enterprises in the crisis period increased significantly, the interaction between financial friction and increasing uncertainty at the enterprise level led to a sharp decline in credit, corporate financing difficulty and financing costs. The sharp increase has led to a greater restriction on cash inflows, which has reduced corporate cash holdings. On the other hand, EPU have a greater impact on corporate cash outflows. Bloom [21] believes that uncertainty increases the size of po- 
tential incentives through the growth of the option effect, thereby encouraging investment and further reducing corporate cash holdings, but Rao Pingui et al.

[6] have found that EPU and corporate investment levels are negative correlation, that is, economic policy uncertainty will reduce the company's cash outflow, thereby increasing the level of corporate cash holdings.

Generally speaking, when enterprises face high EPU, the uncertainty of future expectations of enterprises will increase, and enterprises cannot accurately predict the possibility of cash shortage in the future. For preventive motivation, enterprises will increase cash holdings. On the other hand, when EPU increases, it is easy for management or major shareholders to increase the company's cash flow in order to facilitate their own gains, which will be difficult to be captured by regulators, thereby further increasing the company's cash holding level. We therefore hypothesize the following:

$\mathrm{H} 2$ : EPU is positively correlated with the cash holding level of listed companies.

\subsection{Economic Cycle, EPU and Cash Holding}

Mitchell \& Buns [22] defined the economic cycle as a volatility in a country's overall economic activity, including four continuous and recurring phases: recovery, expansion, boom, and depression. This paper adopts the above division method, with 2004-2015 as the research period, according to the growth rate of GDP. The sample is divided into economic depression period below the lower quartile, and is divided into economic prosperity period above the upper quartile. Under the economic cycle, we study the impact of EPU on the company's cash ratio.

The government's introduction of economic policies can play a multiplier role if it is compatible with the economic cycle. The impact of EPU on the cash holding level of listed companies is asymmetric. When the economy is booming, the active market will increase the amount of investment and reduce the level of cash holdings. At this time, with the increase of EPU, the level of investment in enterprises will decline, and the investment efficiency will increase, so that the level of cash holdings of enterprises will also be rise. On the other hand, during the boom period, the market is in an expanding and active state, and the flow of funds is accelerating. The financing pressure faced by enterprises is relatively small. The cash holdings of enterprises themselves are at a low level. At this time, the increase in EPU will cause enterprises to rapidly increase cash holdings with preventive motives, which is reflected in the immediate response of cash holdings to EPU.

When the economic cycle is in recession, the financing constraints faced by enterprises are relatively large. At this time, the increase of EPU will further increase the financing constraints of enterprises in the short term. Enterprises are subject to an objective financing environment and EPU. It will also increase the amount of corporate investment. In general, the level of corporate cash holdings 
will decrease in the short term, which is reflected as negative correlation between economic policy uncertainty and cash holdings. After a period of time, the market will gradually absorb the impact and gradually reach a new financing equilibrium. The increase in investment volume brought about by EPU will shift the cash shortage cost curve of enterprises. Enterprises will increase cash holding for preventive motive. Based on this, we present the following hypothesis:

H3a: When economic cycle in prosperous, the EPU is positively correlated with the cash holding in the short term. The EPU is still positively correlated with the cash holding in the subsequent stage.

H3b: When economic cycle in recession, the EPU is negatively correlated with the cash holding in the short term. The EPU is positively correlated with the cash holding in the subsequent stage.

\subsection{Economic Cycle, EPU and Cash Holding Value}

MM theory believes that in a friction-free market, cash holding decisions do not affect corporate value, but Chinese economic market is not a frictionless market, so it makes sense to make cash decisions, weighing cash shortfall costs and cash holding costs. It can increase the value of cash holdings, and the theory of free cash flow believes that large shareholders or management will seek illegitimate benefits for themselves by increasing the free cash flow of the company to reduce the cash holding value of the company. Wan Liangyong and Rao Jing [23] found that holding cash to some extent meets the temporary needs of the company's investment, reducing financing costs and enhancing company value. Han Liyan and Liu Boyan [24] believe that corporate governance can increase the value of cash holdings. Yang Xingquan and Zhang Zhaonan [25] also believe that due to the seriousness of the agency problem, state-owned shares will reduce the market value of the company's cash holdings.

On the one hand, when the EPU increase, enterprises will increase the shortage cost curve due to the rising investment level. Increasing the cash holding level can effectively avoid the high external financing constraint cost and financial crisis risk and increase the cash value of the company. On the other hand, according to the free cash flow hypothesis, major shareholders or management usually increase the company's cash holding level to extract corporate interests, increase agency costs, and reduce the company's value when EPU increase. The increase in EPU can provide a reasonable excuse for large shareholders or management to increase cash holdings, and it will also make it more difficult for regulators to supervise them and increase agency costs, which is expected to damage cash value. However, given the outstanding problem of agency costs in China, it is expected that EPU will reduce the value of cash holdings. Based on this paper, the following hypotheses are proposed:

H4: EPU is negatively correlated with the cash holding value.

Further, there are significant differences in the market environment in which enterprises are located in different stages of the economic cycle. The impact of 
EPU on the value of cash holdings may be quite different. When the economy is booming, enterprises face more investment opportunities. Management and major shareholders can control the use of cash to a greater extent. At the same time, the financing constraints faced by enterprises are small, and management and major shareholders can make it easier for enterprises to maintain large amounts of cash. At this stage, the uncertainty of economic policy has increased. On the one hand, it provides a reasonable excuse for management and major shareholders to maintain a large amount of cash for personal gain. On the other hand, the increase in EPU also makes the supervision of agency problems more difficult to implement. It is expected that EPU will reduce the value of corporate cash holdings when the economy is in a prosperous phase. When the economic cycle is in recession, the whole market is in a downturn, and the production and operation of enterprises can only be maintained at a low level. When EPU increases, the company increases cash holdings and reduces bankruptcy due to preventive motives, thereby enhancing corporate value. And in the recession stage, the company's shortage cost reduction is greater than the increase in holding costs, thereby increasing the value of corporate cash holdings. Based on the above analysis, this paper proposes the following hypothesis:

$\mathrm{H} 5 \mathrm{a}$ : When economic cycle in prosperous, EPU is negatively related to the value of corporate cash holdings.

$\mathrm{H} 5 \mathrm{~b}$ : When economic cycle in recession, EPU is positively correlated with the value of corporate cash holdings.

\section{Research Design}

\subsection{Model Design and Variable Definition}

Considering that the research on the cash holding level of listed companies involves a variety of influencing factors, this paper builds the following foundations based on the models set by Opler et al. [14], Jiang Long and Liu Xiaosong [17]. Inspection model:

$$
\begin{aligned}
\mathrm{CASH}_{i, t}= & \alpha_{0}+\alpha_{1} \mathrm{EPU}_{t}+\alpha_{2} \mathrm{Ecocy}_{t}+\alpha_{3} \mathrm{SIZE}_{i, t}+\alpha_{4} \mathrm{SD}_{i, t}+\alpha_{5} \mathrm{MBI}_{i, t} \\
& +\alpha_{6} \mathrm{LEV}_{i, t}+\alpha_{7} \mathrm{NWC}_{i, t}+\text { IndustryEffecy }_{i}+\varepsilon_{i, t}
\end{aligned}
$$

The above model is mainly used to observe the degree of impact of EPU on the cash holdings. Since the response of enterprises to macro factors usually has a certain degree of delay, this paper also verifies the impact of one order lag EPU on the cash holding level of listed companies. The model is as follows:

$$
\begin{aligned}
\mathrm{CASH}_{i, t}= & \alpha_{0}+\alpha_{1} \mathrm{EPU}_{t-1}+\alpha_{2} \mathrm{Ecocy}_{t}+\alpha_{3} \mathrm{SIZE}_{i, t}+\alpha_{4} \mathrm{SD}_{i, t}+\alpha_{5} \mathrm{MBI}_{i, t} \\
& +\alpha_{6} \mathrm{LEV}_{i, t}+\alpha_{7} \mathrm{NWC}_{i, t}+\text { IndustryEffecy }_{i}+\varepsilon_{i, t}
\end{aligned}
$$

In the above model, $\alpha_{k}(k=1,2, \ldots, 7)$ represents the regression coefficient, $i$ represents the company $i, t$ represents the quarter $t$. Industry fixed effects have been added to the model.

In order to explore the direction and extent of EPU on cash holding value, we 
draws on Pinkowitz and Williamson [26], Pinkowitz et al. [27], and Yang Xingquan and Zhang Zhaonan [25] using the revised Fama and French [28]. The cash value regression model is used to test hypothesis 4 and hypothesis 5 . The following formula is a cash value model:

$$
\begin{aligned}
V_{i, t}= & \beta_{0}+\beta_{1} \mathrm{EPU}_{t-1}+\beta_{2} \mathrm{Cash}_{i, t-1}+\beta_{3} \mathrm{EPU}_{t-1} * \mathrm{Cash}_{i, t-1}+\beta_{4} \mathrm{CFO}_{i, t-1}+\beta_{5} d \mathrm{CFO}_{i, t} \\
& +\beta_{6} d \mathrm{CFO}_{i, t-1}+\beta_{7} d \mathrm{NA}_{i, t-1}+\beta_{8} d \mathrm{NA}_{i, t}+\beta_{9} I_{i, t-1}+\beta_{10} d I_{i, t}+\beta_{11} d I_{i, t-1} \\
& +\beta_{12} D_{i, t-1}+\beta_{13} d D_{i, t}+\beta_{14} d D_{i, t-1}+\beta_{12} \mathrm{CAPEX}_{i, t-1}+\beta_{13} d \mathrm{CAPEX}_{i, t} \\
& +\beta_{14} d \mathrm{CAPEX}_{i, t-1}+\beta_{15} d V_{i, t}+\varepsilon_{i, t}
\end{aligned}
$$

In the above model, $\beta_{k}(k=1,2, \ldots, 15)$ represents the regression coefficient, $i$ represents the company $i$, and $t$ represents the year $t$. Since the model is mostly a period variable, in order to eliminate the possible deviation in data extraction, this paper use annual variable in this model. " $t$ " is the current period, $d X_{i, t-1}$ indicates the value of the $t-1$ period variable minus the $t-2$ period value, and $d X_{i, t}$ indicates the value of the $t$ period variable minus $t-1$ period variable.

The main variables involved in several of the above models are described below.

1) Interpreted variables

Cash holding level (CASH). This paper mainly explores the extent to which the cash holding level of listed companies is affected by the macroeconomic environment. Considering the difference between companies' scale, we use size-adjusted cash holding level, which is cash holding of company to the total assets. .In addition to monetary funds, the cash in this indicator also includes short-term investments (pre-2006) and trading financial assets (post-2006).

Corporate value $(V)$. We use the sum of the stock market price of the SFC algorithm and the book value of the debt. The calculation of the stock market price distinguishes between $\mathrm{A}$ shares (including $\mathrm{AB}$ shares) and $\mathrm{B}$ shares, if "(Circulating A shares + restricted A shares) Not equal to 0", then the total market listed shares $=\mathrm{A}$ share closing price $\times$ (total number of shares $-\mathrm{H}-$ overseas shares $-B$ shares $)+B$ shares closing price $\times$ RMB exchange rate ${ }^{\star} B$ shares. If "(Circulation A shares + Restricted A shares) $=0$ " and "B shares total not equal to 0 ", then the total market value $=\mathrm{B}$ shares closing price $\times \mathrm{RMB}$ exchange rate $\times B$ shares total shares.

2) Explanatory variables

Economic Policy Uncertainty (EPU). Economic Policy Uncertainty is one of the systemic risks faced by enterprises, and it will have different degrees of impact on various decisions of enterprises. This paper draws on the data of China's economic policy uncertainty developed by Baker et al. [29] and uses the calculation method of Rao Pingui et al. [6] to calculate the uncertainty of quarterly economic policy.

3) Adjustment variables

Economic cycle (Ecocy). The prosperity and recession of the macroeconomic environment directly affects the extent of changes in the country's GDP. At present, China's economic market is generally in the development stage, and the 
changes of economic cycle will affect the speed of China's market development. This paper represents the economic cycle by GDP growth rate.

4) Control variables

Refer to Opler et al. [14], Lu Zhengfei and Zhu Jigao [4], Jiang Long and Liu Xiaosong [17] and other documents. In the basic model, we introduces company scale (SIZE), main business income (MBI), assets and liabilities (LEV), net working capital ratio (NWC), short-term debt ratio (SD), industry, etc. The control variables involved in the cash value model include operating cash flow ratio (CFO), non-cash asset ratio (NA), interest expense ratio (I), cash dividend payout ratio $(D)$, and capital expenditure ratio (CAPEX) (Table 1 ).

\subsection{Sample Selection and Data Source}

We takes the listed companies of Shanghai and Shenzhen A-shares as the research object, and selects the data from the first quarter of 2004 to the fourth quarter of 2015 to form a research sample for the following reasons: The proxy variables of the macroeconomic policy (monetary policy) can only be obtained by 2015 . The economic cycle generally takes 10 years as a cycle and the model needs to lag two phases. We further screens the sample: 1) Eliminate relevant missing variables during the study period; 2) Excluding companies that have

Table 1. Variable description table.

\begin{tabular}{|c|c|c|c|}
\hline Category & Variable Name & Symbol & Variable Description \\
\hline \multirow{2}{*}{ Interpreted variables } & Cash holding Rate & CASH & Cash holdings/total assets \\
\hline & Corporation Value & $V$ & $\{$ Stock market price $(\mathrm{CSRC})+$ debt book value $\} /$ total assets \\
\hline \multicolumn{2}{|c|}{ Explanatory variables Economic Policy Uncertainty } & EPU & $\begin{array}{l}\text { Drawing on China's economic policy uncertainty index developed by Baker et } \\
\text { al. [29] }\left(\frac{3 \mathrm{EPU}_{m}+2 \mathrm{EPU}_{m-1}+\mathrm{EPU}_{m-2}}{6}\right) / 100\end{array}$ \\
\hline \multirow[t]{7}{*}{ Adjustment variables } & Economic Cycle & Ecocy & GDP quarterly growth rate \\
\hline & Company Size & SIZE & The natural logarithm of the company's total assets \\
\hline & Main Business Income level & MBI & The natural logarithm of the main business income of the current period \\
\hline & Assets and Liabilities & LEV & Total liabilities for the current period/total assets of the period \\
\hline & Net Working Capital ratio & NWC & $\begin{array}{l}\text { (Working capital - one monetary fund - short-term investment)/total assets at } \\
\text { the end of the period }\end{array}$ \\
\hline & Short-term Debt ratio & SD & Current short-term borrowings/current assets \\
\hline & Industry & Industry & Industry dummy variable, CSRC (2012) standard \\
\hline \multirow[t]{5}{*}{ Control variables } & Operating Cash Flow ratio & $\mathrm{CFO}$ & Net cash flow from operations/(total assets - cash holdings) \\
\hline & Non-cash Asset ratio & NA & (total assets - cash holdings)/total assets \\
\hline & Interest Expense ratio & $I$ & Financial expenses interest expenses (including capitalized interest)/total assets \\
\hline & Cash Dividend payout ratio & $D$ & Cash dividends/total assets issued in the current period \\
\hline & Capital Expenditure ratio & CAPEX & $\begin{array}{l}\text { Capital Expenditure/(Total Assets - Cash Holdings) Capital Expenditure = } \\
\text { Cash paid for operating leases + Cash for purchase and construction of fixed } \\
\text { assets, intangible assets and other long-term assets - Disposal of fixed assets, } \\
\text { intangible assets and other long-term assets }\end{array}$ \\
\hline
\end{tabular}


been listed for less than two years during the study period or declared ST or PT; 3) Excluding financial listed companies. Finally, all continuous variables are winsorized at the top and bottom $1 \%$ levels to mitigate the influence of extreme values, and finally a total of 79,919 valid sample data from 2004 to 2015 were obtained. The financial data of this paper mainly comes from Wind database. The macro data mainly comes from Csmar Economic and Financial Research Database. The EPU comes from the "China Economic Policy Uncertainty Index" developed by Baker et al. [29]. We use STATA 14.0 and EXCEL to process data.

\section{Empirical Process and Test Results}

\subsection{Descriptive Statistics}

Table 2 reports the descriptive statistics for the main variables in this paper. The mean value of the explanatory variable cash holding rate (CASHR) is $18.9 \%$, which is similar to the statistics of Jiang Long and Liu Xiaosong [17], and the difference in cash holding ratio between different listed companies is obvious, the maximum is $71 \%$, the smallest is only $0.8 \%$, and the median cash holding rate of listed companies is $14.5 \%$, indicating that most listed companies have low cash holdings. The average value of the market value $(V)$ is 2.438 , which means that the market value of the listed company is on average higher than the book value of $143.8 \%$, and the minimum value is 0.73 , indicating that there is a listed company whose market value is lower than the book value. The maximum value is 10.168 , indicating the existence of highly recognized companies. The explanatory variable economic policy uncertainty (EPU) average is 1.37 , the minimum and maximum values are 0.54 and 3.23 respectively, and the median is 1.19 , indicating that economic policy uncertainty fluctuates greatly, and economic policy uncertainty was below average during most periods

\subsection{Test Results of the Impact of the Economic Cycle on the Cash Holding}

Column (1) of Table 3 presents the baseline regression without the main terms. The $\mathrm{R}^{2}$ is 0.4535 , more than 0.45 , which indicates that the overall model fit well. The coefficients of the net working capital ratio (NWC) and the company scale (SIZE) are negative and significant at the $1 \%$ level respectively, indicating that the higher net working capital ratio, or the larger company size, the lower cash holding ratio. There was a significant negative correlation between the financial leverage and the corporate cash-holding ratio. The cash holding level was significantly positively correlated with the income level of the main business, and was significantly negatively correlated with the short-term bank loan interest rate. Column (2) presents the regression containing the economic cycle variable based on baseline regression, and the coefficient of the economic cycle is significantly negative, indicating that in the case of economic prosperity, the enterprise 
Table 2. Descriptive statistics of the main variables.

\begin{tabular}{ccccccccc}
\hline Variable & Size & Mean & S.D. & Min & $\begin{array}{c}\text { Lower } \\
\text { quartile }\end{array}$ & Median & $\begin{array}{c}\text { Upper } \\
\text { quartile }\end{array}$ & Max \\
\hline CASHR & 79,919 & 0.189 & 0.148 & 0.008 & 0.084 & 0.145 & 0.247 & 0.710 \\
$V$ & 80,840 & 2.438 & 1.664 & 0.730 & 1.365 & 1.911 & 2.888 & 10.168 \\
EPU & 79,919 & 1.371 & 0.703 & 0.540 & 0.870 & 1.190 & 1.644 & 3.232 \\
Ecocy & 79,919 & 9.326 & 2.207 & 6.2 & 7.5 & 8.3 & 10.9 & 14.3 \\
SIZE & 79,919 & 21.72 & 1.24 & 19.30 & 20.84 & 21.55 & 22.39 & 25.56 \\
MBI & 79,919 & 20.49 & 1.59 & 16.51 & 19.43 & 20.41 & 21.45 & 24.78 \\
LEV & 79,919 & 0.451 & 0.211 & 0.044 & 0.288 & 0.460 & 0.613 & 0.897 \\
NWC & 79,919 & 0.187 & 0.267 & -0.410 & 0.0003 & 0.167 & 0.363 & 0.827 \\
SD & 79,919 & 0.126 & 0.118 & 0 & 0.019 & 0.101 & 0.202 & 0.472 \\
\hline
\end{tabular}

Table 3. Regression analysis of the first model.

\begin{tabular}{|c|c|c|c|c|c|c|c|c|}
\hline \multirow{2}{*}{ Variable } & \multirow{2}{*}{$\begin{array}{l}\text { Benchmark } \\
\text { model (1) }\end{array}$} & \multirow{2}{*}{ GDP (2) } & \multirow{2}{*}{ EPU (3) } & \multirow{2}{*}{$\mathrm{EPU}_{t-1}(4)$} & \multicolumn{2}{|c|}{ Prosperous period } & \multicolumn{2}{|c|}{ Recession } \\
\hline & & & & & EPU (5) & $\mathrm{EPU}_{t-1}(6)$ & EPU (7) & $\mathrm{EPU}_{t-1}(8)$ \\
\hline EPU & & & $0.0068^{\star * *}$ & & $0.0238^{\star * *}$ & & $-0.0046^{* * *}$ & \\
\hline $\mathrm{EPU}_{t-1}$ & & & & $0.0117^{\star * *}$ & & $0.0464^{\star * *}$ & & $0.0271^{\star * *}$ \\
\hline Ecocy & & $-0.0039^{* * *}$ & $-0.0048^{\star * *}$ & $-0.0048^{\star * *}$ & -0.0007 & $0.0011^{*}$ & -0.0020 & $0.0078^{\star * *}$ \\
\hline SIZE & $-0.0086^{\star \star \star}$ & $-0.0063^{* * *}$ & $-0.0057^{\star * *}$ & $-0.0045^{\star \star \star}$ & $-0.0038^{\star * *}$ & $-0.0060^{* * *}$ & $-0.0086^{* * *}$ & $-0.0061^{\star * *}$ \\
\hline MBI & $0.0073^{\star * *}$ & $0.0066^{* * *}$ & $0.0060^{* * *}$ & $0.0052^{\star * *}$ & $0.0081^{* * *}$ & $0.0099^{\star * *}$ & $0.0062^{\star * *}$ & $0.0045^{\star * *}$ \\
\hline LEV & $-0.0228^{\star * *}$ & $-0.0238^{* * *}$ & $-0.0231^{* * *}$ & $-0.0219^{\star * *}$ & -0.0032 & -0.0065 & $0.0143^{* * *}$ & $0.0133^{*}$ \\
\hline NWC & $0.3767^{\star * *}$ & $0.3812^{* * *}$ & $0.3807^{* * *}$ & $0.3690^{* * *}$ & $0.4006^{* * *}$ & $0.3852^{* * *}$ & $0.3074^{* * *}$ & $0.3020^{* * *}$ \\
\hline $\mathrm{SD}$ & $0.0557^{\star * *}$ & $0.0509^{\star * \star}$ & $0.0510^{\star * *}$ & $0.0462^{\star * *}$ & $0.0453^{\star * \star}$ & $0.0455^{\star * \star}$ & $0.0502^{\star * \star}$ & $0.0460^{* * *}$ \\
\hline Ind & Control & Control & Control & Control & Control & Control & Control & Control \\
\hline _con & $0.1404^{* * *}$ & $0.0678^{\star * *}$ & $0.0502^{\star * *}$ & $0.0366^{\star * *}$ & 0.0032 & -0.0262 & $0.1636^{* * *}$ & 0.0365 \\
\hline $\mathrm{N}$ & 79915 & 79915 & 79915 & 79915 & 22432 & 22220 & 23814 & 23500 \\
\hline R-square & 0.4535 & 0.4565 & 0.4575 & 0.4437 & 0.4752 & 0.4825 & 0.3289 & 0.3279 \\
\hline F (prob.) & 3317.1 & 3197.7 & 3062.7 & 2800.4 & 1195.8 & 1219.5 & 531.56 & 522.16 \\
\hline
\end{tabular}

${ }^{*} \mathrm{p}<0.10,{ }^{* *} \mathrm{p}<0.05,{ }^{* * *} \mathrm{p}<0.01$.

will invest more, thereby reducing the cash holding level. These results support H1.

\subsection{Test Results of the Impact of Economic Cycle and EPU on the Cash Holding}

Columns (3) and (4) of Table 3 report the regressions of the current period EPU and one order lag EPU on the listed company's cash holding level. According to the regression results, the coefficient of EPU in both the current period and the lag period is significantly positive, indicating that when the EPU increases, the 
company will increase the cash holding level for preventive motives, which has certain lag effect. The result is consistent with Hypothesis 2.

We divides the economic cycle into four groups by descending order of GDP growth rate to study the impact of macroeconomic policies on the cash holding of listed companies under different economic cycle periods. The first quarter is divided into the prosperity group, and the last quarter is divided into the recession group.

Columns (5)-(8) of Table 3 report the impact of the EPU on the cash holdings of listed companies in different stages of the economic cycle. In general, the four regressions in Table 3 are all have large $\mathrm{R}^{2}$, which is more than 0.32 , indicating that the model fits well. Columns (5) and (6) report the regression results of EPU and the level of cash holdings of enterprises in the period of economic prosperity. It can be seen from the regression results that the impact of economic policies on corporate cash holdings during the boom period has a certain lag, and the coefficient of the first-order lag variable is significantly larger than the coefficient of the original variable, indicating the impact of EPU on the current period of the enterprise is significantly smaller, compared with the next phase. So this paper only considers the first-order lag variable in the subsequent cash value model. When the economic cycle is in prosperous stage, the EPU in the short term is positively correlated with the cash holding level of listed companies. The EPU in the subsequent stage is still positively correlated with the cash holding level of listed companies, which is consistent with Hypothesis 3a.

Columns (7) and (8) represent the regression of EPU and the level of cash holdings of enterprises in the period of economic recession. From the regression results, it can be seen that when the economy in recession, the EPU will further increase the financing pressure of enterprises in the short term, which reflects the decline of cash holdings of enterprises. However, after a period of time, companies further increase cash holdings for preventive motivation. In the economic recession, the EPU in the short term is negatively correlated with the cash holding level of listed companies. The EPU in the subsequent stage is positively correlated with the cash holding level of listed companies, which is consistent with the setting of hypothesis $3 \mathrm{~b}$.

\subsection{Test Results of the Impact of Economic Cycle and EPU on the Cash Holding Value}

Table 4 reports the results of the research hypothesis 4 , the impact of the regression results of EPU on the cash holdings value of enterprises, and hypothesis 5, the impact of the regression results of EPU on the cash holdings value of enterprises in different economic cycle environments. The adjusted $\mathrm{R}^{2}$ was greater than 0.22 , indicating that the model fits well. Column (1) of Table 4 presents the baseline regression of the cash holding value model of listed companies without EPU. The coefficient of cash holding is positive, indicating that holding cash is valuable to enterprises. Column (2) reports the regression result of the cash value model after adding the EPU based on the baseline regression. It can be seen 
Table 4. Regression analysis of the cash value model.

\begin{tabular}{|c|c|c|c|c|}
\hline \multirow{2}{*}{ Variable } & \multirow{2}{*}{$\begin{array}{c}\text { Benchmark } \\
\text { model (1) }\end{array}$} & \multirow{2}{*}{ GDP (2) } & \multicolumn{2}{|c|}{ EPU } \\
\hline & & & Prosperity (3) & Recession (4) \\
\hline CASHR & $1.588^{* * *}$ & $0.413^{* *}$ & 0.491 & $6.146^{\star * *}$ \\
\hline $\mathrm{EPU}_{t-1}$ & & $0.053^{\star *}$ & $0.900^{* * *}$ & $-0.260^{* *}$ \\
\hline $\mathrm{CASHR} \times \mathrm{EPU}_{t-1}$ & & $-0.811^{\star * *}$ & -0.657 & $0.768^{* * *}$ \\
\hline $\mathrm{CFO}_{i, t-1}$ & $3.209^{\star * *}$ & $2.934^{* * *}$ & $2.384^{* * *}$ & $1.873^{\star * *}$ \\
\hline$d \mathrm{CFO}_{i, t}$ & $0.817^{* * *}$ & $0.726^{* * *}$ & 0.204 & 0.412 \\
\hline$d \mathrm{CFO}_{i, t-1}$ & $-1.136^{\star * \star}$ & $-0.957^{\star * *}$ & 0.065 & $-1.176^{\star * \star}$ \\
\hline$d \mathrm{NA}_{i, t}$ & $0.048^{\star * \star *}$ & $0.178^{\star \star *}$ & 0.157 & $1.472^{\star * *}$ \\
\hline$d \mathrm{NA}_{i, t-1}$ & -0.455 & -0.297 & $1.012^{* * *}$ & $-1.666^{\star * *}$ \\
\hline$I_{i, t-1}$ & $-1.688^{\star * *}$ & $-1.550^{* * *}$ & $1.742^{\star * *}$ & $-6.148^{\star * *}$ \\
\hline$d I_{i, t}$ & $-2.950^{\star * \star}$ & $-2.872^{\star * *}$ & $-1.043^{\star * *}$ & $-6.259^{* * *}$ \\
\hline$d I_{i, t-1}$ & $-2.284^{\star * \star}$ & $-2.186^{* * *}$ & $-2.603^{\star * \star}$ & -0.348 \\
\hline$D_{i, t-1}$ & $-2.077^{\star * *}$ & $-2.001^{\star * \star}$ & $-2.821^{\star \star \star}$ & $-6.417^{\star \star \star}$ \\
\hline$d D_{i, t}$ & 0.047 & 0.061 & -0.067 & 2.121 \\
\hline$d D_{i, t-1}$ & $1.302^{* * *}$ & $1.276^{* * *}$ & $1.204^{* * *}$ & $4.776^{* * *}$ \\
\hline CAPEX $_{i, t-1}$ & $4.194^{\star * *}$ & $3.711^{* * *}$ & $4.268^{* * *}$ & $-2.577^{\star \star \star}$ \\
\hline$d \mathrm{CAPEX}_{i, t}$ & $1.254^{\star * *}$ & $0.934^{\star * *}$ & $1.922^{\star * *}$ & $-1.441^{\star *}$ \\
\hline$d \mathrm{CAPEX}_{i, t-1}$ & $-1.116^{* * *}$ & $-1.141^{\star * *}$ & $-2.328^{* * *}$ & $1.139^{\star *}$ \\
\hline$d V_{i, t}$ & $-0.494^{\star * *}$ & $-0.505^{\star * *}$ & $-0.541^{\star * *}$ & $-0.437^{\star * *}$ \\
\hline _con & $2.525^{\star * *}$ & $2.374^{* * *}$ & $1.115^{* * *}$ & $3.506^{* * *}$ \\
\hline $\mathrm{N}$ & 25969 & 25969 & 6687 & 7579 \\
\hline $\mathrm{R}$-square & 0.2692 & 0.2218 & 0.3711 & 0.3533 \\
\hline F (prob.) & 598.79 & 405.85 & 220.22 & 231.04 \\
\hline
\end{tabular}

${ }^{*} \mathrm{p}<0.10,{ }^{* *} \mathrm{p}<0.05,{ }^{* * *} \mathrm{p}<0.01$.

from the table that the coefficient of the intersection term is negative and statistically significant at the $5 \%$ level, indicating that EPU will reduce the market value of cash holdings, and the EPU may increase the agency cost and reduce its market value. This is consistent with the statement of Hypothesis 4, which confirms the agency channel of EPU on the cash-hold value. Columns (3) and (4) report the result of the impact of EPU on the cash holding value of enterprises in different economic cycle stages. Columns (3) lists the regression results of the EPU on the cash holding value of the enterprise when the economic cycle is in prosperous stage. From the Table 4, it can be seen that the coefficient of the intersection term is negative, but not significant. To a certain extent, it proves that during the boom period, the financing constraints of enterprises are small, and the agency costs will increase when economic policy uncertainty increases, thus reducing the market value of corporate cash holdings. However, since the coeffi- 
cient is not significant, it cannot directly prove hypothesis 5 a. Columns (4) lists the regression results of EPU on corporate cash holding value when the economic cycle is in recession stage. It can be seen from Table 4 that the coefficient of the intersection term is positive and statistically significant at the $1 \%$ level, suggests that the increasing uncertainty will increase the cash holding and the cash holding cost while significantly reducing the cash shortage cost, thereby increasing the market value of the company's cash holdings, which is consistent with Hypothesis $5 b$.

\subsection{Robustness Test}

Since the economic cycle and EPU are macroeconomic factors, they are highly exogenous to enterprises, so we do not consider the endogeneity of the model. In this paper, the robustness test is carried out in the following way, and the regression results are almost indistinguishable from the corresponding regression results in the text above.

1) Change the variable: change the division of the economic cycle. We use the method of economic cycle division of Jiang Long and Liu Xiaosong [17] in the test of robustness; the enterprise value in the previous article adopts the CSRC method of the market price calculation. Calculate the ratio of the stock market value and the book value of total liabilities to the total assets. In the regression of robustness, we refer to the calculation method of stock market value which sated by Yang Xingquan and Zhang Zhaonan [25].

2) Change period: Since the economic cycle is usually divided into 10 years, and the cash value model needs to lag two periods. Therefore, this paper selects the data for the 12-year period from 2004 to 2015, and further increases the research period in the robustness regression to 2004-2017. It was found that there was almost no change in the regression results; In the test of Hypothesis 2, only the one-stage lag variable was used for the relationship between EPU and the late cash holding level of listed companies, and more was adopted in the robustness regression. We found that there is no longer significant impact on the cash holdings after the two periods of lag, so the lag effect of economic policy uncertainty may only exist in the one order lag period.

\section{Conclusions and Recommendations}

This paper takes the listed companies in China from 2004 to 2015 as a research sample, and examines the impact of economic cycle and EPU on the cash holding decision of listed companies in the macroeconomic environment. The empirical results show that economic cycle is significantly negatively correlated with the cash holding level of listed companies, while EPU is significantly positively correlated with cash holdings. The result of the combined effect of economic cycle and EPU is that: during the economic boom period, the impact of EPU on the current or late cash holding level of listed companies is significantly positive; during the recession, EPU is significantly negatively correlated with the 
current cash holding level of listed companies, while the level of cash holdings in the late period is significantly positive, which indicates that cash holdings of enterprises has greater financing constraints brought by EPU, which is reflected in the decline of cash holdings in the short-term, and after the market has absorbed the impact of the financing constraints, the impact of EPU on cash holdings is more manifested in expectations theory.

This paper further examines the role of economic cycle and EPU on the value of cash holdings of listed companies. The empirical results show that EPU will reduce the cash holding value of listed companies. When the economy is booming, the increase in EPU will reduce the market value of cash holdings, but it is not significant. When the economy is in recession, the increase in EPU will increase the market value of corporate cash holdings. Therefore, the significance of this paper is to remind policy makers to distinguish the economic cycle from the stage of economic cycle when introducing policies. When the economy is booming, it should play more roles in the market and reduce the intervention in the market. In the recession period, appropriate policy intervention is beneficial to the whole market.

\section{Conflicts of Interest}

The author declares no conflicts of interest regarding the publication of this paper.

\section{References}

[1] Keynes, J.M. (1936) The General Theory of Employment Interest and Money. Harcourt Brace, London.

[2] Vinod, V. (2011) Partial Adjustment toward Optimal Cash Holding Levels. Review of Financial Economics, 20, 113-121. https://doi.org/10.1016/j.rfe.2011.06.002

[3] Zhang, W.J. (2014) Monetary Policy Shocks, Financing Constraints and Corporate Cash Holdings-Also on the Effectiveness of Monetary Policy in the Real Estate Market. Finance and Trade Research, No. 4, 126-131.

[4] Lu, Z.F. and Zhu, J.G. (2008) Monetary Policy and Changes in Cash Holding Level of Listed Companies. Proceedings of the 7 th International Symposium on Empirical Accounting in China, 391-402.

[5] Duchin, R., Ozbas, O. and Sensoy, A. (2010) Costly External Finance Corporate Investment and the Subprime Mortgage Credit Crisis. Journal of Financial Economics, 9, 418-435. https://doi.org/10.1016/j.jfineco.2009.12.008

[6] Rao, P.G., Yue, H. and Jiang, G.H. (2017) Research on Economic Policy Uncertainty and Corporate Investment Behavior. World Economy, No. 2, 27-51.

[7] Johannsen, B.K. (2014) When Are the Effects of Fiscal Policy Uncertainty Large? FEDS Working Paper, 40.

[8] Mumtaz, H. and Zanetti, F. (2013) The Impact of the Volatility of Monetary Policy Shocks. Journal of Money, Credit and Banking, 45, 535-558. https://doi.org/10.1111/jmcb.12015

[9] Lee, J. (2013) Does an Aggregate Increase in Idiosyncratic Volatility Cause a Recession? Emory Economics 1312, Department of Economics, Emory University (At- 
lanta).

[10] Guney, Y., Ozkan, A. and Ozkan, N. (2007) International Evidence on the Non-Linear Impact of Leverage on Corporate Cash Holdings. Journal of Multinational Financial Management, 17, 45-60. https://doi.org/10.1016/j.mulfin.2006.03.003

[11] Bates, T.W., Kahle, K.M. and Stulz, R.M. (2009) Why Do U.S. Firms Hold So Much More Cash Than They Used to? Journal of Finance, 64, 1985-2021. https://doi.org/10.1111/j.1540-6261.2009.01492.x

[12] Campello, M. (2003) Capital Structure and Product Market Interactions: Evidence from Business Cycles. Journal of Financial Economics, 68, 353-378. https://doi.org/10.1016/S0304-405X(03)00070-9

[13] Fazzri, S.M., Hubbard, R.G. and Petersen, B.C. (1998) Financing Constraints and Corporate Investment. Brookings Papers on Economic Activity, 1, 141-195.

[14] Opler, T., Pinkowitz, L., Stulz, R. and Williamson, R. (1999) The Determinants and Implications of Corporate Cash Holdings. Journal of Financial Economics, 52, 3-46. https://doi.org/10.1016/S0304-405X(99)00003-3

[15] Bernanke, B. (1983) Irreversibility, Uncertainty, and Cyclical Investment. Quarterly Journal of Economics, 98, 85-106. https://doi.org/10.2307/1885568

[16] Baum, C.F., Caglayan, M., Stephan, A. and Talavera, O. (2008) Uncertainty Determinants of Corporate Liquidity. Economic Modeling, 25, 833-849.

https://doi.org/10.1016/j.econmod.2007.11.006

[17] Jiang, L. and Liu, X. (2011) Research on Economic Cycle Fluctuation and Cash Holdings Behavior of Listed Companies. Accounting Research, 9, 40-46.

[18] Ni, H. and Zhao, S. (2013) Controlling Shareholder Increase, Reduction and Capital Occupation-Based on the Research of China's A-Share Listed Companies in 2009-2011. Securities Market Herald, 4, 62-68.

[19] Wang, H., Li, Q. and Xing, F. (2014) Economic Policy Uncertainty and Cash Holdings Level and Its Market Value. Financial Research, 9, 53-68.

[20] Bai, Y., et al. (2011) Financial Markets and Fluctuations in Uncertainty. Society for Economic Dynamics, Meeting Papers 896.

[21] Bloom, N. (2014) Fluctuations in Uncertainty. Journal of Economic Perspectives, 28, 153-175. https://doi.org/10.1257/jep.28.2.153

[22] Mitchell, M. and Mulherin, J. (1996) The Impact of Industry Shocks on Takeover and Restructuring Activity. Journal of Financial Economics, 41, 193-229. https://doi.org/10.1016/0304-405X(95)00860-H

[23] Wan, L. and Rao, J. (2013) Uncertainty, Financial Crisis Impact and Cash Holding Value-An Empirical Study Based on Chinese Listed Companies. Journal of Economics and Management, 5, 63-71.

[24] Han, L. and Liu, B. (2011) Corporate Governance, Uncertainty and Cash Value. Economics Quarterly, 2, 523-550.

[25] Yang, X. and Zhang, Z. (2008) Institutional Environment, Equity Nature and Cash Value of Corporate Holding. Economic Research, 12, 111-123.

[26] Pinkowitz, I. and Williamson, R. (2001) Bank Power and Cash Holdings: Evidence from Japan. Review of Financial Studies, 14, 1059-1082. https://doi.org/10.1093/rfs/14.4.1059

[27] Pinkowitz, J.D. and Wong, T.J. (2012) Institutions and Information Environment of Chinese Listed Firms. In: Fan, J. and Morck, R., Eds., Capitalizing China, University of Chicago Press, Chicago, 201-242. 
[28] Fama, E.F. and French, K.R. (1988) Permanent and Temporary Components of Stock Prices. Journal of Political Economy, 96, 246-273.

https://www.jstor.org/stable/1833108

[29] Baker, S., Bloom, N., Davis, S.J. and Wang (2013) A Measure Economic Policy Uncertainty for China. Working Paper, University of Chicago, Chicago. 